Discussion Papers of the

Max Planck Institute for

Research on Collective Goods

2019/13

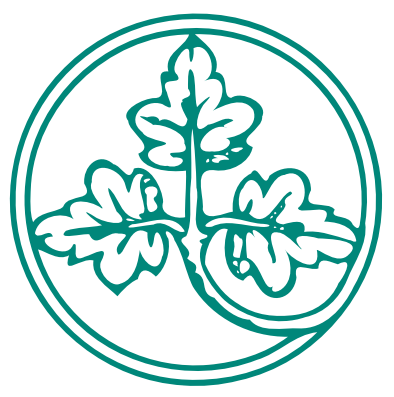

Banks, Politics and

European Monetary Union

Martin Hellwig 


\title{
Banks, Politics and European Monetary Union
}

\author{
Martin Hellwig
}

November 2019 


\title{
Banks, Politics and European Monetary Union ${ }^{1}$
}

\author{
By Martin Hellwig
}

\begin{abstract}
This contribution to the panel on the future to EMU discusses the tensions that arise from the fact that banks are, on the one hand, an essential element of the monetary transmission mechanism and, on the other hand, an integral part of local, regional or national polities. Banking union can eliminate or at least reduce some of the procrastination that has allowed maintained bank weaknesses to persist and harmed the transmission of monetary policy but, whereas the SSM has been fairly successful, resolution is still not working properly and needs further reforms. At the same time, banking union suffers from the problem that interventions from Brussels or Frankfurt are seen as infringements of national sovereignty that lack political legitimacy. The conflict between supranational and national interests is ultimately irresolvable but, if EMU is to survive, measures must be taken to limit its impact.
\end{abstract}

Key Words: Monetary union, central banking, politics of banks, banking union, bank resolution, bail-in.

JEL Classifications: E42, E44, E51, G18, G28, G33

\footnotetext{
${ }^{1}$ Contribution to a panel on "The Future of EMU" at the 2019 ECB Forum on Central Banking in Sintra, June 2019.

https://www.ecb.europa.eu/pub/pdf/sintra/ecb.forumcentbank201911 e0dd97f2c0.en.pdf
} 


\section{Introduction}

Any discussion of the future of EMU must consider the question whether this monetary union will survive. On this question, political developments of the past ten years must give us pause. In some member states, we have seen the rise of populism with strong anti-EU and anti-EMU leanings. If this development continues, the very existence of EMU and perhaps the EU as a whole will be challenged.

The challenge to EMU is political rather than economic. Money is a source of power. Central banking is political even though we like to think of it as technical. Therefore, the central bank needs political legitimacy. Political legitimacy is based on public trust and public discourse, not just on the legal norms that empower the central bank. Thus, in the past, the Bundesbank's independence rested on its power to mobilize public opinion, rather than the law, which could have been changed at any time by a simple majority of the Bundestag; mobilization of public opinion made such a change prohibitively costly. ${ }^{2}$ For a supranational institution like the ECB, the task of maintaining political legitimacy is even more challenging because public political discourse in the euro area is mostly national.

In the first decade of EMU, the problem hardly arose. This decade saw what may be called a depolitization of monetary policy. Whereas before EMU monetary policy and its relation to fiscal policy and wage setting had persistently been a matter of public debate, in the first decade of EMU, monetary policy disappeared from the headlines. Media discussion of monetary policy concerned exchange rate movements, the appropriate level of transparency, or the two-pillar approach - nothing to raise political emotions. $^{3}$

All this changed with the financial crisis of 2007-2009 and the "euro crisis" since 2010. The difference between the second and the first decade of EMU is not just the difference between monetary policy in normal times and in a time of crisis. In the second decade of EMU there also was a repolitization of monetary policy, a return of monetary policy to the headlines, the focus of public discussion. Initially, in the financial crisis, this repolitization concerned the support that central banks and governments brought to financial institutions. Subsequently, the repolitization concerned the measures taken to contain the "euro crisis", with a fragmentation of public discourse along national lines, involving discussions about bailouts in some countries and about austerity in others.

2 Thus Chancellor Adenauer's 1956 attempt to prevent an increase in central-bank interest rates and Finance Minister Waigel's 1997 initiative to revalue the Bundesbank's gold reserves in order to warrant an extra payout to the government triggered public outcries and were quickly withdrawn.

See Hellwig (2007). 
In this context, the supranational character of EU institutions is a source of weakness rather than strength, for the ECB as well as the European Commission. To be sure, political discourse in the member states cannot directly affect them, but since they are not a part of this discourse, they are also not in a position to defuse the criticisms that are raised. Participation in discourse however is important for mobilizing political support and defending against national populism that aims at undermining the basis for European integration.

The problem is not just a by-product of the crises but is endemic to EMU. Whereas monetary policy is supranational, its effects are felt by people and by institutions that operate in political spheres of discourse that are national.

The tension is particularly strong in the area of banking. On the one hand, banks are an essential part of the monetary system. The payments system depends on banks and the central bank relies on banks for the transmission of monetary policy measures to the overall economy. On the other hand, banks are also an essential part of their respective national or even regional economies and polities. A lot of banking is national, or even local, - and it is political because funding by banks plays a key role in the communities where they are located.

The role of banks in EMU, their position between supranational and national authorities, poses a major conundrum. In the following, I will discuss this conundrum and its significance for the future of EMU.

\section{Banking Union is Essential for European Monetary Union}

When EMU was founded, the role of banks in the monetary system was given little consideration. The Treaty asks the ECB to "contribute to the smooth conduct of policies pursued by the competent authorities relating to the prudential supervision of credit institutions and the stability of the financial system" (Art 127 (5) TFEU). The Treaty also gives the Council the power to introduce special legislation to "confer specific tasks upon the European Central Bank concerning policies relating to the prudential supervision of credit institutions and other financial institutions with the exception of insurance undertakings" (Art. 127 (6) TFEU). Both formulations seem concerned with the assistance that the ECB can provide to competent supervisory authorities, rather than the functioning of monetary policy. Before the advent of banking union, of course, competent supervisory authorities were institutions of the member states.

At the time, the lender-of-the-last-resort role of central banks was also given little consideration. Subsequent memoranda of understanding minimized such a role, stipulating that solvency problems were to be dealt with by member state governments, liquid- 
ity problems of individual banks by national central banks' provision of emergency liquidity assistance (ELA), and liquidity problems of the entire system by the ECB through appropriate market interventions. ${ }^{4}$ The possibility that member state governments might be unable or unwilling to deal with solvency problems was not considered. Neither was the possibility that some markets might break down and that market interventions might not be sufficient for liquidity provision to the system.

During the first decade of EMU, these omissions did not matter. Concerns about bank solvency did not play any role, and liquidity was always available through wholesale markets. Interbank markets contributed to an integration of monetary systems that went much farther than the fragmentation of banking systems along national lines might have led one to expect.

With the financial crisis of 2007-2009, however, concerns about bank solvency became prominent, and wholesale markets froze. Interbank lending, including cross-border interbank lending, broke down, and liquidity became a major issue for banks. Even after the interventions of governments and central banks had stopped the crisis, the system did not return to its previous mode of functioning. As the "euro crisis" developed, in 2009-2012, capital flows were even reversed as interbank loans were recalled or not renewed and securities from periphery countries were sold.

For monetary policy, these developments created serious challenges: First, how to deal with the liquidity crises; second, how to implement a unified monetary policy with fragmented banking systems when interbank markets could not be relied upon to link the economies of different countries. Third, how to make monetary policy effective when transmission to the real economy was hampered by the fact that large parts of banking systems were on the brink of insolvency. Of these challenges, the first one was met by radical action, with large injections of liquidity in 2007/08 and again in 2011/12. The second one was met by moving to a full allotment rule allocating central bank loans to commercial banks on the basis of expressed demand. The third challenge, however, lay outside the domain of central-bank power.

A paradigmatic example is given by the finding of Acharya and Steffen (2013) that loans provided under the Eurosystem's Long Term Refinancing Operation (LTRO) of 2011/12 were most attractive to weak banks and that these banks were more likely than others to use the money for lending to their own governments rather than the real economy. The LTRO was very successful in stopping the financial turmoil that had started in the summer and fall of 2011, but the ECB's assured funding of commercial banks only partly resulted in additional lending to the real economy.

In this context, national and supranational institutions, governments and central banks may have different interests and incentives. Whereas the central bank needs healthy 
commercial banks for an effective transmission of monetary policy, national authorities sometimes find it convenient to procrastinate when "their" banks are in trouble. ${ }^{5}$ Supervisors may want to procrastinate because they want to avoid a public discussion about the causes of the difficulties. Governments may want to procrastinate because they fear the need to use public money to recapitalize banks; the LTRO experience suggests that they may also see the weakness of commercial banks as a way to get indirect access to the printing press. Central banks themselves may want to procrastinate because they fear that the turmoil associated with an intervention might cause further systemic damage.

However, kicking the can down the road rarely has the consequence that the problems disappear on their own. Most of the times, delays aggravate the problems and make subsequent resolution even costlier. ${ }^{6}$ Moreover, timely recognition and resolution of banking problems are essential for the implementation and transmission of monetary policy when the central bank uses commercial banks to bring central bank money into the economy.

Banking union can be understood as an attempt to address this issue. The Single Supervisory Mechanism (SSM) takes banking supervision out of the national domain and gives the ECB the power to oversee systemically important institutions in the euro area, to ask for corrective measures if they see problems, and to ask for resolution by competent authorities if other measures are not available. In this work, the ECB-supervisors cooperate with the national supervisors and may depend on the national supervisors' information about "their" financial institutions, but, in matters concerning the application of European legal norms, the national supervisors themselves are acting as part of the SSM and are independent of their governments, most importantly, their finance ministers.

In my view, the SSM has been remarkably successful. Beginning with the comprehensive assessment and stress test in 2014, the SSM has contributed a lot to making banks recognize losses on problem loans that the national supervisors had long overlooked, for example, losses on loans to the shipping industry. ${ }^{7}$ The SSM also contributed to making banks raise new equity, some of it in anticipation of asset assessments and stress tests, some of it in response to the shortfalls that the assessments and stress tests uncovered.

Hellwig $(2014 \mathrm{a}, \mathrm{b})$.

ASC (2012).

Ever since 2008, excess capacity has made it difficult for shipping companies to earn the margins above variable costs that they need to service their debt, let alone earn a return on equity. As construction orders from before the crisis were being completed, capacity growth continued long after 2008, so excess capacity persisted even after world trade had recovered from its 2008 collapse. For a detailed discussion, see Hellwig (2018b). 
Even so, important parts of euro area banking systems remain weak. The weakness reflects the extent and the depth of the financial crises since 2007. It also reflects the fact that, in the area of resolution, banking union has not been very successful. The Bank Recovery and Resolution Directive (BRRD) and the Single Resolution Mechanism Regulation (SRM) have moved bank resolution partly to the supranational level, but only partly, and the new arrangements are not working well.

When the BRRD and the SRM Regulation were drawn up, no attention seems to have been paid to the fact that, even in resolution, some provisions must be made to ensure that the bank remains liquid. In the case of the Spanish bank Banco Popular Español (BPE), resolution had to take place overnight, through a shotgun sale to Banco Santander, because otherwise the bank would have run out of cash and defaulted the next day. The BRRD recognizes the importance of short-term funding of banks and exempts some of it from bail-in, but neither the BRRD nor the SRM Regulation say anything about what is to happen if there is a run by short-term financiers, depositors or money market funds. ${ }^{8}$ The legislators seem to have thought that the resolution procedure does not require much time, but if investors are afraid and run, there may be no time at all before the bank runs out of cash. In the case of BPE, there was a run by depositors, and the authorities did not even have the time for a proper valuation in support of the bail-in they imposed on the holders of equity and subordinated debt. ${ }^{9}$

National authorities have tried to avoid the SRM as much as possible. In the case of the Italian banks, Monte dei Paschi di Siena as well as Banca Popolare di Vicenza and Veneto Banca, intervention was much delayed by protracted negotiations between the Italian government and the European Commission's state aid control unit over the question whether precautionary recapitalizations proposed by the government were compatible with the European rules on state aid. Eventually, Monte dei Paschi was recapitalized and the other two banks were wound down under national law. ${ }^{10}$ In the case of HSH Nordbank, the regional governments of Hamburg and Schleswig-Holstein as

8 In ordinary insolvency law, the problem is much less acute and can be handled by freezing old debt and giving priority to new debt when a company goes into bankruptcy. With banks, such a rule is problematic: If the short-term debt is frozen, the systemic implications for, e.g. money market funds can be disastrous, as in the case of the Lehman Brothers bankruptcy inducing the Reserve Primary Fund to break the buck, triggering a dramatic run of investors on money market funds, and causing the subsequent freeze of money markets. If the short-term debt is not frozen, funding needs are likely to be so large that merely giving the new (or renewed) claims priority over frozen old debt may not be enough to fill these needs. For a detailed discussion, see Hellwig (2014b).

9 The bank was declared failing or likely to fail on June 6, 2017 and resolved on June 7. The resolution decision relied on an independent valuation that the Single Resolution Board (SRB) had ordered on May 23, 2017. However, the valuation report noted that the time span of 13 days had been too short to provide more than a provisional valuation. For a detailed discussion, see Hellwig (2018a).

10 The Single Resolution Board decided that Banca Popolare di Vicenza and Veneto Banca were not important enough to warrant application of the SRM and entrusted the Italian authorities with the task of winding them down. 
owners of the bank accepted additional costs to taxpayers of over two billion euros in order to avoid a winding down of the bank. In the political deliberations in Hamburg, the government suggested that yielding control to the SRM would induce additional losses as there was no viable regime for an orderly winding down of the bank. This case also had dragged on for a long time. ${ }^{11}$

The persistence of high levels of non-performing loans must also be seen in this context. Over the past two years, these levels have been reduced, but they remain very high, in some countries dangerously so. Industry resistance against a further cleanup is strong: such a cleanup might require substantial recapitalizations or even closures, which would impose losses on incumbent shareholders, perhaps even debtholders. ${ }^{12}$ Last year's dispute about the SSM's proposal to enhance provisioning against losses on non-performing loans has shown that, in its resistance, the industry enjoys strong support from political forces. Resistance against bank cleanups also comes from stakeholders such as borrowers and political authorities that have become used to benefiting from the presence and conduct of the banks in question.

In summary, we do not yet have a viable system for dealing with banks in difficulties. In part, the problem is technical, for example in the lack of viable arrangements for funding banks during the resolution process (also during the process of winding them down if that is the preferred option) ${ }^{13}$. In part, the problem is political, for example in the distributive conflicts involved in the recognition and attribution of losses to different parties. However, the resulting delays in bank cleanups cause the weaknesses of banking systems to persist. To the extent that these weaknesses are due to excess capacity and low profitability, the delays also contribute to maintaining the excess capacities and to preventing a restoration of bank profitability that might help the industry to recapitalize by retaining earnings.

From the perspective of monetary union, it is essential to have a reform of banking union that makes resolution viable, enabling a cleanup of the industry that reduces the frictions in the transmission of monetary policy. As a contribution to the much vaunted "completion of banking union", a reform of bank resolution is even more important than the introduction of a European deposits insurance system. Deposit insurance may actually be irrelevant if the arrangements for resolution are not trustworthy and resolution is never entered into.

11 In the summer of 2013, the regional governments applied to the European Commission for permission to increase their second-loss guarantee to the bank from seven to ten billion euros. In 2015, the Commission agreed, but insisted on the bank being sold to private investors by 2018 , or else wound down.

12 For an account of incentive distortions causing incumbent shareholders to resist recapitalizations even if they would be efficient, see Admati et al. (2018).

13 In the case of Banca Popolare di Vicenza and Veneto Banca, the Italian authorities had to rely on a special procedure outside of standard insolvency law, relying on Intesa Sanpaolo for funding the winding down of bad loans. 


\section{Banking Union lacks Political Legitimacy}

Whereas banking union is needed to provide monetary union with a financial-sector infrastructure that permits smooth transmission of monetary policy, at the same time, banking union lacks political legitimacy. The resistance against viable and speedy bank resolution is only one symptom of a deep-seated feeling that banks are an important part of local, regional, and national polities with which supranational authorities should not meddle.

There are several reasons why banks are political. ${ }^{14}$ First, banks are a source of money, and everyone in the polity has an idea of what the money should do. Politicians know that "their" banks should fund "worthy" purposes. For example, the German Landesbanken, public-sector banks that are owned by the Länder, have a tradition of providing funding for favoured projects of the heads of "their" regional governments. ${ }^{15}$ Providing loans to politically important clienteles, such as (prospective) homeowners and small and medium entrepreneurs, is also an activity that has a political dimension. Homeowners are sufficiently numerous so their vote matters. Entrepreneurs are less numerous but the multiplier effects of their attitudes and activities can be very significant.

Second, many governments regard banking itself as a suitable domain for industrial policy. Before the financial crisis of 2008, the ease of attracting funds on a large scale tempted the governments of several countries, among them Cyprus, Iceland, and Ireland, to promote the growth of the financial sector as a fast route to economic development. In other countries, governments wanted to see "their" major banks as "champions" in global markets. Recent efforts of the German Finance ministry to promote a merger of Deutsche Bank and Commerzbank must be seen in this light. ${ }^{16}$ One may also remember that the 2000 merger of Banque Nationale de Paris and Banque Paribas was very much welcomed by the French authorities; they actually would have liked to see Société Générale to join as well.

Third, investors in banks are often important players in national political systems. Depositors in banks are even more numerous than homeowners so their vote is also im-

14 For an extensive discussion of the politics of banking, see Chapter 12 in Admati and Hellwig (2013).

15 Thus, as part of the Bavarian government's strategy to turn Munich into a centre of the media industry, in the 1990s, BayernLB provided substantial funding for the expansion of the Kirch media empire. In 2008, HSH Nordbank supported the Hamburg government's takeover of a substantial share in the shipping company Hapag Lloyd by purchasing a significant share, thus reducing the part of the acquisition cost that had to go through the government budget. Both investments caused significant losses as Kirch became insolvent in 2002 and Hapag Lloyd made losses due to the worldwide shipping crisis.

16 In 2004 already, Chancellor Schröder called upon German banks to create a national champion; one may also assume that the 2008 takeover/rescue of Dresdner by Commerzbank was undertaken with an understanding that government support would be available if needed as indeed it was later in the year. 
portant. Institutional investors with larger stakes may matter because of their importance in public discourse. In the case of the German bank Hypo Real Estate, the bailout of all creditors by the German government benefited not only institutions like the insurer Allianz and Deutsche Bank, but also the established churches, public television organizations, municipalities, social retirement institutions. ${ }^{17}$ Banco Popular Español (BPE) had significant deposit funding from regional entities, such as cities and districts, whose deposits exceeded the statutory limit of $€ 100.000$ for deposit insurance, which is why these investors were anxious to run when an insolvency of BPE became likely. In the cases of Monte dei Paschi di Siena and the two Venetian banks, the bail-in of CET 1 and CET 2 titles affected non-financial private investors such as small entrepreneurs who had been told that, because of an insufficiency of equity, their bank had to restrict their loans, but if they were to invest their private wealth in preferred stock of the bank, the resulting increase in the bank's equity would permit continued lending.

Given these concerns, the members of national polities consider banking union to be an intrusion into their territory. BRRD, SSM, SRM, and the Commission's state-aid control are seen as illegitimate infringements of national sovereignty. Thus, in Italy, the bail-in imposed on investors was a major cause of the political discontent that led to the change of government after the 2018 election.

From the perspective of Sunday school teaching, many of the political concerns that I sketched are problematic. Using political power to obtain privileged funding for the government's preferred projects or clienteles amounts to a subversion of the parliament's budget authority. To be sure, at first sight, there is no cost to the government, but if things go wrong for the banks, the government will have to step in, as the national and regional governments did in Germany in 2008 and as the Italian government did in the case of Monte dei Paschi. Industrial-policy promotion of banks at the expense of their safety imposes risks on the polity and on others; for example, in the years before 2008 , the toleration of special-purpose vehicles as a means of holding mortgagebacked securities without equity backing was motivated by national-champions objectives and contributed a lot to the damage from the crisis. ${ }^{18}$ And the use of bailouts to protect creditors from sharing in banks' losses is a subversion of the principle that everyone is liable for the consequences of their own actions, a principle which is fundamental to people's being free to do what they want in a market economy. To the extent that investments in preferred stock or subordinated debt were induced by misrepresentations from the sellers, such misrepresentations and the toleration of such practices by the authorities were scandalous.

17 Thus, Hannes Rehm, the CEO of the German bailout fund SoFFin, in an interview given to Frankfurter Allgemeine Zeitung in March 2009.

18 For details, see Thiemann (2012). 
However, legitimacy from the perspective of Sunday school teaching is not the same as political legitimacy. Political legitimacy is a result of public discourse in a given polity and, ultimately, of elections. In the European Union as currently constructed, public political discourse as a source of political legitimacy works at the local, regional, or national level, but not at the supranational level. Public discourse about supranational actions is fragmented between the different national polities. Within any one polity, interference from Brussels or Frankfurt is treated as illegitimate regardless of what its actual merits may be. The supranational actors themselves are not much present in this discourse, and anyone taking their side must fear being treated as an outsider.

The conflict is reinforced if the ECB uses the power it has to influence national policies, as it did in Ireland in 2010, Italy in 2011, and Greece in 2015. Since banks depend on the ECB for liquidity, the ECB has significant power over them and, indirectly, over national payment systems and national economies. The use of this power, actually or by threats, to influence national governments adds to the supranational interference that national polities resent.

One must also take account of the fact the Sunday school teaching is not always "right". Economists do not really have much to say about appropriate policies towards asymmetric shocks that stem from the uncertainties of the capitalist system. Whereas some asymmetric shocks are due to moral hazard, in real-estate bubbles or excessive sovereign borrowing, others are due to changes in comparative advantage in global markets. For example, Northern Italy has been much affected by competition from transition/accession countries and from China. With regional specialization, such shocks affect entire regional economies, including regional banks; the Venetian banks provide an example.

How to deal with such asymmetric shocks is an open question, a challenge for supervision, resolution, and regional policy, at the level of the EU as well as the national or regional level. In the United States, Federal spending and Federal unemployment insurance serve as stabilizers. In the EU, we have no analogue of these devices; nor do people find it as easy to move between regions as in the United States. As for the proper levels at which to deal with the problems caused by asymmetric shocks, it is worth observing that the decline of coal and steel industries seems to have induced much greater discontent and susceptibility to populism in Northern England and Northern France than in the Ruhr area in Germany; I suspect the difference has a lot to do with policy centralization in the United Kingdom and France versus federal decentralization in Germany. The success of nationalist populism in the area of the former GDR fits the pattern because economic policy there was in large part determined by politicians and experts from West Germany. 


\section{The Bank-Sovereign Nexus and the Future of EMU}

The conflict between supranational and national concerns in the area of banking is ultimately irresolvable. In discussions about banking union, one often hears about the need to "cut the bank-sovereign nexus". The formulation was used by the June 2012 Summit to explain the creation of banking union, ${ }^{19}$ but it has never been clear what precisely it meant. In current discussions, it is often used to justify the need for a European Deposit Insurance Scheme (EDIS), in the sense that the conditions at which banks obtain deposits and therefore the credibility of guarantee schemes should not depend on the sovereign.

Such discussions however do not go to the heart of the matter. As long as member states are sovereign, there will always be a bank-sovereign nexus that cannot be cut. Any bank is located in some member state and is subject to the law of that state. Supervision, resolution, and deposit insurance are not the only links between the state and the bank. Employment law and tax law also play a role, and the sovereign has threats that can affect the way banks behave. The ultimate threat is that of nationalization, an admittedly very extreme assertion of sovereignty, which had however been planned by the Greek Finance Minister as part of an exit strategy in 2015.

I do not believe that transnational banks will solve the problem. On the one hand, such banks will still be subject to the political will of the sovereign in the country where they have their headquarters. I cannot imagine Monsieur le Président de la République Française accepting a limit on the exercise of sovereign power towards BNP Paribas on the grounds that BNP Paribas is a European bank. On the other hand, such banks may exacerbate the problem of asymmetric shocks in those areas where they do not have their headquarters. Headquarters may not have much understanding for the needs of such "outlying areas". ${ }^{20}$

In terms of political institutions, it would be desirable to have more of a supranational source of political legitimacy, at the level of the executive and of the legislature. Just a finance minister with a budget is not sufficient for this purpose. We need political powers of the executive and legislature whose exercise induces public discussion that links up across national borders.

19 At the time, Spain had asked for direct ESM contributions to the recapitalization of Spanish banks; the SSM was ostensibly introduced to preclude any moral hazard from such an arrangement. However, the legislation took so long that the recapitalization of Spanish banks was funded by the government anyway, with ESM support for the Spanish government.

20 In this context, it is worth noting that, in Germany in 2009, the dissociation of the local savings banks and cooperative banks from developments in the global financial system contributed a lot to limiting the credit crunch that the crisis induced. The credit crunch affected mainly the clients of large private banks and Landesbanken that had been involved in global markets. For details, see Hellwig (2018b). 
We should also think again about the principles underlying the BRRD and the Commission's state aid control. I am all in favour of bail-in, rather than bailout. However, in some instances, precautionary recapitalizations may be called for to avoid negative repercussions of resolution and closures. For those circumstances, we need to rethink the role of state aid control. In 2008, the Commission's state aid control was adapted to the emergency of the crisis. Since then, it has provided almost the only limit to bank bailouts. Such a limit is necessary because, if all banks are bailed out, excess capacities will be maintained forever, banks may never again become sustainably profitable, and monetary policy will never get out of the lurch in which it has been since 2008 .

As currently conceived, state aid control is a device to protect competition in the internal market. I often have a sense that the rules developed in that context may not quite fit in the context of bank bailouts (precautionary recapitalizations). Can we really think of bail-ins as an instance of the private-investor rule? And how much attention should we pay to the information capital of banks that know their local customers - as well as the lack of information capital at potential new entrants that might replace the banks that are closed?

Ever since European integration started with the Schuman Plan, academics have had a tradition of being pessimistic. First the European Communities, then the European Union, did not fit into our categories for the dealings of different countries with each other. In a sense, Europe has been like the proverbial bumble bee: every specialist in aerodynamics "knows" that the bumble bee cannot fly; its body is too heavy, and its wings are too small. But bumble bees do fly and refute the wisdom of the theorists. Unlike the bumble bee, the European Communities and the European Union have not stuck to the same design, but have improved their design over time as problems arose. These improvements have been essential to the survival and the success of the European project. I very much hope that such improvements will happen in the area of banking union, not only to make it work better, but also to reduce the potential for damage from the underlying conflict between national sovereignty and supranational monetary policy.

\section{References}

Admati, Anat R., and Martin F. Hellwig (2013), The Bankers' New Clothes, Princeton University Press, Princeton, N.J.

Admati, Anat R., Peter M. DeMarzo, Martin F. Hellwig, and Paul Pfleiderer (2018), "The Leverage Ratchet Effect", Journal of Finance 73 (2018), 145 - 198. 
ASC (2012), "Forbearance, resolution and deposit insurance", Report 01/2012, Reports of the Advisory Scientific Committee of the European Systemic Risk Board, Report $01 / 2012$.

Hellwig, Martin F. (2007), "Switzerland and Euroland: European Monetary Union, Monetary Stability, and Financial Stability", in: Swiss National Bank (ed.), The Swiss National Bank 1907-2007, Zürich 2007.

Hellwig, Martin F. (2014a), "Financial Stability, Monetary Policy, Banking Supervision, and Central Banking", in: European Central Bank (ed.), ECB Forum on Central Banking: Monetary Policy in a Changing Financial Landscape: Conference Proceedings 2014, 2154 .

Hellwig, Martin F. (2014b), "Yes, Virginia, there is a European Banking Union! But it may not make your wishes come true", in: Austrian National Bank (ed.), Towards a European Banking Union: Taking Stock - Proceedings of the 42nd Economics Conference 2014, 2014, $156-181$.

Hellwig, Martin F. (2018a), "Valuation Reports in the Context of Banking Resolution", Report prepared for the European Parliament's Committee on Monetary and Economic Affairs, Preprint 2018/06, Max Planck Institute for Research on Collective Goods, Bonn.

Hellwig, Martin F. (2018b), "Germany and the Financial Crises 2007-2017 - Case Study on a Past Crisis: The Case of Germany", Paper presented at the fourth Annual Macroprudential Conference of the Swedish Riksbank, June 2018.

Thiemann, Matthias (2012), "Out of the Shadow? Accounting for Special Purpose Entities in European Banking Systems", Competition and Change 16, 37 - 55. 